\title{
逐次推定法による圧延のロール偏心制御*
}

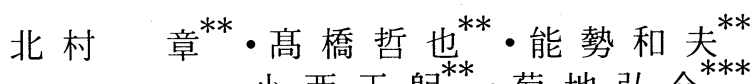 \\ 小西正躬 ${ }^{* *}$ ・菊地弘介 ${ }^{* * *}$
}

\section{Roll Eccentricity Control Based on Recursive Estimation Technique*}

\author{
Akira Kitamura ${ }^{* *}$, Tetsuya TAKahashi ${ }^{* *}$, Kazuo Nose**, \\ Masami KonISHI ${ }^{* *}$ and Kousuke $\mathrm{KIKUCHI}^{* * *}$
}

\begin{abstract}
This paper discusses a new roll eccentricity control method which has the following features ; the roll eccentricity is modeled by a sine wave equation for each roll and the eccentricity parameters, such as amplitude and initial phase angle are estimated using the recursive estimation technique. In this method, a square root filter is used to prevent the parameters from diverging. In addition, Kalman filter and exponentially weighted least square estimation are applied to decrease the estimation error due to the variance of observation noise and the gradual variation in force offset respectively. Furthermore, the convergence of parameters is automatically checked observing the trace of error convariance matrix. This control method is aplied to the first stand of tandem cold mill as a roll eccentricity control system. The convergence of recursive computation is confirmed and both the force and thickness deviation due to roll eccentricity have been reduced to less than half.
\end{abstract}

\section{1.はじめに}

帯鋼の圧延を始めとする圧延機では, 圧延ロールの軸 受中心亡胴部中心に幾何学的な偏心がある. また, 圧延 時の噛み止めによりロール冷却が不均一になることから ロール表面の温度分布に熱的偏りが生じ, 付加的な偏心 となる. これらの偏心は, バックアップロールで, 数 $\mu$ から数十 $\mu$ に達し，板厚変動の一因となっている.

ロール偏心はロール 1 回転ごとの周期的変動であるた めに高周波の板厚外乱をひき起こしており, 圧延機出側 に設置された X 線板厚計によるフィードバック制御で は無駄時間のために追従できないばかりでなく，ゲージ メータ $\mathrm{AGC}^{1,2}$ に対しては誤制御の原因となっている. そこで，偏心の影響を除去するには専用の制御システム

* 原稿受付 1988.9. 30

** 神戸製鋼所 電子技術研究所 Electronics Research Laboratory, Kobe Steel, Ltd. ; 5-5, Takatsukadai 1-chome, Nishiku, Kobe 673-02, JAPAN

*** (神戸製鋼所 加古川製鉄所 Kakogawa Works, Kobe Steel, Ltd. ; 1, Kanazawacho, Kakogawa 675-01, JAPAN

Key Words : roll eccentricity control, recursive estimation, square root filter, Kalman filter, exponentially weighted least square estimation.
が必要である.

ロール偏心の推定方法としては, バックアップロール の偏心を制御対象として, 圧延中の荷重データに対して フーリエ変換を用いる方法 ${ }^{3,4}$, 偏心による荷重変動を 直接メモリし，ロール径差による上下ロールの位相差の 変化を利用して各ロールの偏心波形を抽出する方法 ${ }^{5}$, ロール回転周波数相当のバンドパスフィルタを用いる方 法 ${ }^{6}$ など, 各種の方法が提案されている. 参考文献 3) では, 幾何学的偏心には十分対応できない, 参考文献 4） では，圧延中に発生する付加的な偏心に対応する機能が ない, 参考文献 5) では, 各ロールの偏心パラメータ（偏 心量と初期位相角）を推定する方法ではないために, 偏 心以外の外乱を反映する可能性がある. 参考文献 6) で は, フィルタ処理のために位相遅れが生じ, その補償が 困難である，という問題がある.

そこで，筆者らは，ロール固有の幾何学的偏心に対し ては多段ミルの全ロール偏心を同一モデルで表現し, 同 時に推定する機能として, ロール回転中の荷重データに 逐次推定方法を適用し, 偏心パラメータを時間領域で時々 刻々推定するオフライン推定法を開発した。

また，圧延中に発生する付加的な偏心に対しては，偏 心の最む大きいロールに着目して圧延中の荷重データに 
逐次推定法を適用して, 偏心波形を時間領域で推定し, 制御するオンライン推定法を開発した. また，乙れら二 つの方法からなるロール偏心制御システムを構筑した.

本稿では, 開発したロール偏心の推定方法の詳細と, ロール偏心制御システムの実機適用結果について述べる.

\section{2. ロール偏心制御の必要性}

\section{1 ロール偏心とは}

ロール偏心として，ロール軸受け中心と胴部中心の間 に偏心を考える. 上下一対のロールで構成される圧延機 の場合, 偏心による板厚変動は, Fig. 1 に示すように,

$$
\Delta h_{e e}=\frac{M_{0}}{M_{0}+Q(1-\rho)} A(t) \cdot \sin \left(\omega_{0} t+B(t)\right)
$$

となる。

$$
\begin{array}{ll}
\text { ただし, } & A(t)=F_{1}\left(e_{T}, e_{B}, \Delta \omega, t\right) \\
& B(t)=F_{2}\left(e_{T}, e_{B}, \Delta \omega, t\right) \\
& \omega_{0}=\frac{\omega_{T}+\omega_{B}}{2}, \Delta \omega=\frac{\omega_{T}-\omega_{B}}{2} \\
& v=R_{T} \omega_{T}=R_{B} \omega_{B}
\end{array}
$$

ここで,

$M_{0}$ : ミル定教, $\quad Q$ : 圧延材の塑性係数

$R_{T}$ : 上ロールの半径, $R_{B}$ : 下ロールの半径

$e_{T}$ : 上ロールの偏心量, $e_{B}$ : 下ロールの偏心量

$v:$ 圧延速度 $\quad \omega_{T}:$ 上ロールの角速度

$\rho:$ チューニング率 $\quad \omega_{B}:$ 下ロールの角速度 $(0<\rho<1)$

$t$ : 時間

（1）式は, ロール偏心による板厚 (荷重) 変動が上下口 一ルの径差のために振幅, “位相とあに時々刻々変化して ゆくことを示して抢り，偏心を制御するには，乙れらを 考慮した方法が必要となる.

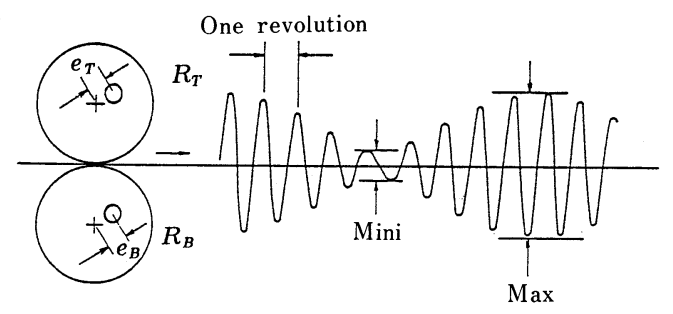

Fig. 1 Thickness deviation due to roll eccentricity

\section{2 ロール偏心制御と AGC}

Fig. 2.1 にゲージメータ AGCの概念図を示し Fig. 2.2 にその制御ブロックを示す. Fig. 2.2 より, ロール 偏心 $(\Delta e)$ と入側板厚偏差 $(\Delta H)$ のステップ外乱が加わっ た場合, 最終值の定理を用いて定常偏差を求めると,

$$
\begin{aligned}
\Delta h & =\lim _{s \rightarrow 0} s \cdot G_{e}(s) \frac{\Delta e}{s}+\lim _{s \rightarrow \infty} s \cdot G_{H}(s) \frac{\Delta H}{s} \\
& =\frac{M_{0}}{M_{0}+Q(1-\rho)} \Delta e+\frac{\partial P / \partial H}{M_{0} /(1-\rho)+Q} \Delta H
\end{aligned}
$$

となる ${ }^{1,2}$.

ここで, $G_{e}(s)$ は, ロール偏心に関する伝達関数, $G_{H}(s)$ は, 入側板厚外乱に関する伝達関数を表わす.

また, Fig. 2.3 では, $\Delta h$ とチューニング率 $\rho$ の関係 を示す. 本図より, $\rho$ を大きくすると $\Delta H$ による出側

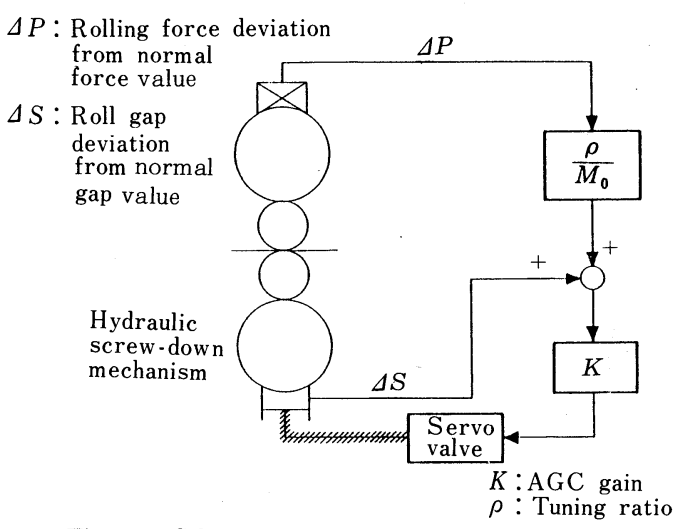

Fig. 2.1 Schematic diagram of gaugemeter AGC

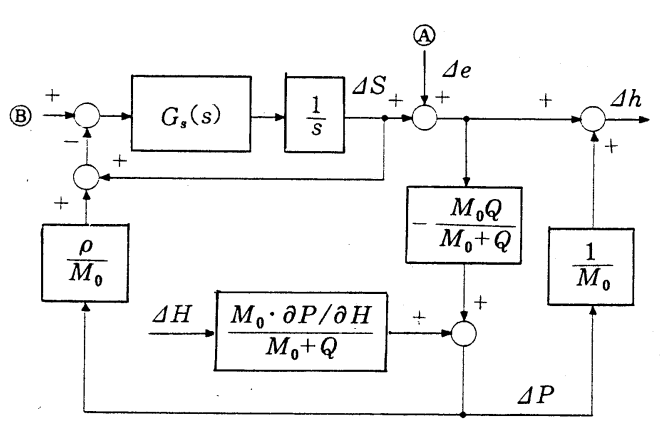

Fig. 2.2 Block diagram of gaugemeter AGC

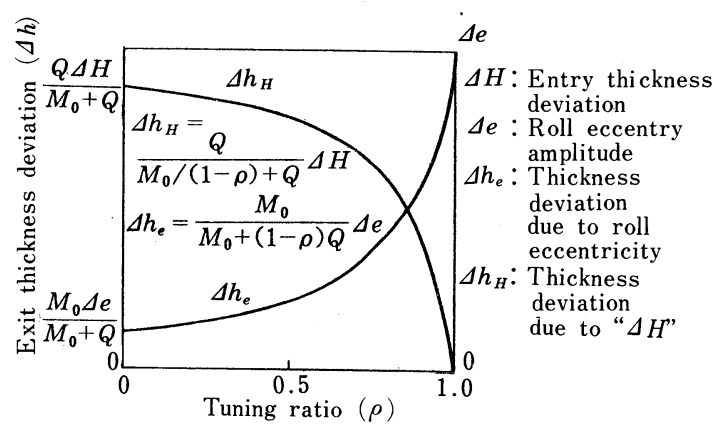

Fig. 2.3 Relationship between gaugemeter AGC and roll eccentricity 


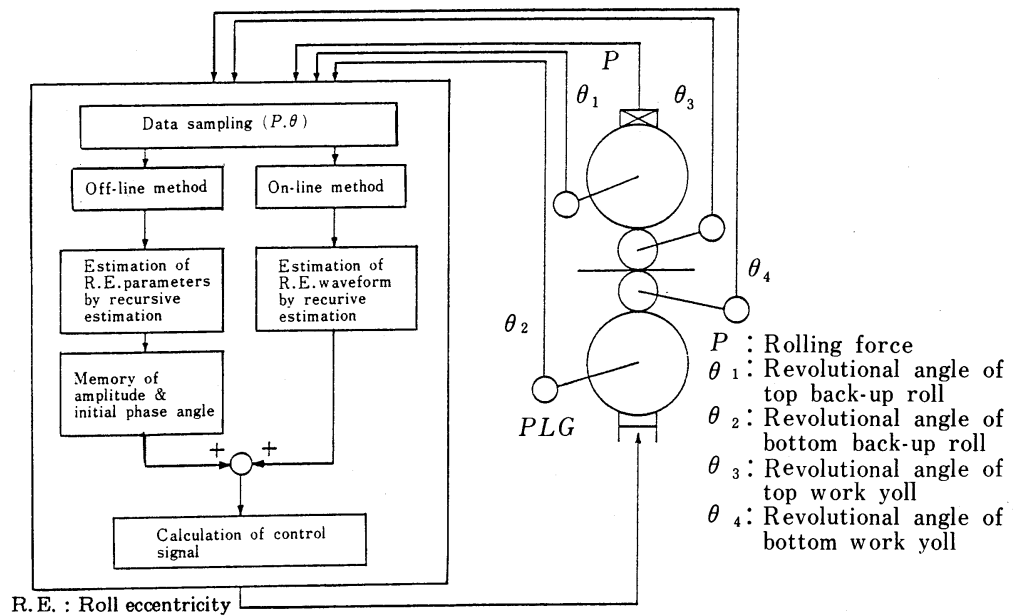

Fig. 3 Schematic diagram of roll eccentricity control system

板厚偏差 $\Delta h_{H}$ （(2) 式の右辺第 2 項）は小さくなるが, $\Delta e$ による偏差 $\Delta h_{e}$ ((2) 式の右辺第 1 項) が大きくな る.乙れは，偏心がゲージメータ AGCに対して誤制御 の原因となり，ロール偏心専用の制御システムが必要で あることを示している.

\section{3. 制御システム}

ロール偏心制御システムの概略図を Fig. 3 に示す. 圧延荷重 $(P)$ とパルスジェネレータ (PLG) によって 測定されたロール回転角 $(\theta)$ を用いて偏心波形を推定し, それに基づいて圧延中に偏心の影響を打ち消すように口 一ル間隙を補償する. 波形の推定法としては, 以下に述 ベるオフライン推定法とオンライン推定法を組み合わせ ている.

\section{1 オフライン推定法}

本方法は, ロール固有の幾何学的な偏心に対応するも ので，ロール替え時などにキスロール状態でロールを回 転させ, その荷重変動から各ロールの偏心量と位相量を 推定する. 圧延時には, 推定量に基づいて予測制御にて, 圧下を補償する.

ここでは 4 段圧延機を想定し，オフライン推定法で用 いるロール偏心推定用モデルについて述べる. モデルの 概念を Fig. 4 亿示す. いま, $k$ 番目のサンプリングパ ルスに同期して得られた荷重 $(P)$ から, ロックオン荷 重（噛み込み直後の荷重值）を差し引いた偏心による荷 重変動 $\Delta P_{e f}(k)$ を各ロールの $n_{i}$ 次高調波までの正弦 波の噛み合わせと考えると次式となる.

$$
\begin{aligned}
\Delta P_{e f}(k)= & M \cdot \sum_{i=1}^{4} \sum_{m=1}^{n i} e_{i m} \cdot \sin \left(m \theta_{i}(k)+\phi_{i m}\right) \\
& +P_{0}(k)+\Delta P_{\varepsilon}(k) \quad(k=1,2, \cdots)
\end{aligned}
$$

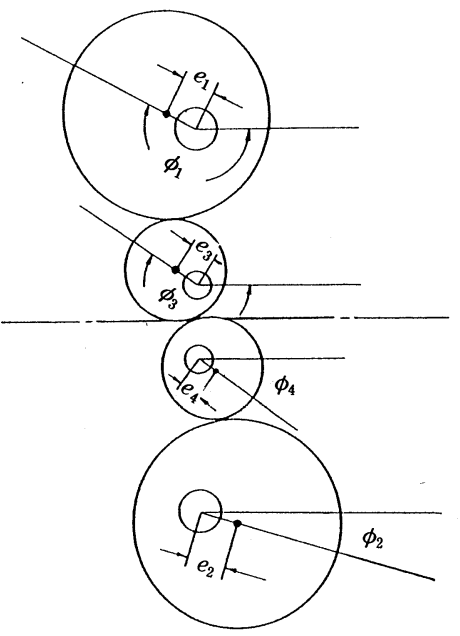

Fig. 4 Roll eccentricity parameters for the "Off-line estimation method"

ここで, $i:$ 各ロールの番号

$e_{i m}:$ 第 $i$ ロールの $m$ 次偏心振幅

$\phi_{i m}$ : 第 $i$ ロールの $m$ 次偏心初期位相角

$\theta_{i}(k):$ 第 $i$ ロールの回転角

$n i$ : 第 $i$ ロールの高調波成分の次数

$P_{0}(k)$ : 荷重オフセット量

$\Delta P_{\varepsilon}(k):$ 観測雑音

$$
\begin{aligned}
& M: \text { 等価ミル定数 }\left(=\frac{M_{0}}{(1-\rho)}\right) \\
& k: \text { サンプリングパルスのナンバー }
\end{aligned}
$$

つぎに，観測值 $\theta_{i}(k)$ で構成されるべクトル $\boldsymbol{a}(k)$ と末 知パラメータ $e, \phi, P_{0}(k)$ で構成されるベクトル $x(k)$ を次式で定義する. 


$$
\begin{gathered}
\boldsymbol{a}(k)=\left(\sin \theta_{1}(k), \cos \theta_{1}(k), \sin 2 \theta_{1}(k), \cos 2 \theta_{1}(k),\right. \\
\cdots, \sin \left(n 1 \theta_{1}(k)\right), \cos \left(n 1 \theta_{1}(k)\right), \sin \theta_{2}(k), \\
\left.\cos \theta_{2}(k), \cdots, \sin \left(n 4 \theta_{4}(k)\right), \cos \left(n 4 \theta_{4}(k)\right), 1\right) \\
x=\left(X_{1}|, \cdots,| X_{4} \mid X_{0}\right)^{T} \\
X_{i}=\left(X_{i 1}, X_{i 2}, \cdots, X_{i, 2 n i}\right)^{T} \\
\text { ただし, } X_{i, 2 j-1}=M \cdot e_{i j} \cos \phi_{i j} \\
X_{i, 2 j}=M \cdot e_{i j} \sin \phi_{i j} \\
X_{0}=P_{0}(k) \quad(j=1,2, \cdots, n i)
\end{gathered}
$$

これらの関係より，（3）式を展開し，ベクトル表現 すると次式となる。

$$
\Delta P_{e f}(k)=\boldsymbol{a}(k) \cdot x(k)+\Delta P_{\varepsilon}(k)
$$

ここで，未知べクトル $x$ が推定できると，偏心パラメ 一夕 $e, \phi$ は (4-2) 式の関係から, 下式で求めることが できる。

$$
\begin{aligned}
e_{i j} & =\sqrt{X_{i, 2 j-1}^{2}+X_{i, 2 j}^{2}} / M \\
\phi_{i j} & =\tan ^{-1} \frac{X_{i, 2 j}}{X_{i, 2 j-1}}
\end{aligned}
$$

また，荷重オフセット量 $P_{0}$ は， $X_{0}$ として求まる.

てれらの関係から，逐次推定法を用いて偏心パラメー 夕を推定することができる，乙のように，本方法では， 各ロールの偏心パラメータを推定するてとによって, 口 ール径差によって生じる偏心波形の振幅と位相の変化に 追従することができる.

\section{2 オンライン推定法}

本方法は，圧延時の噛み止めによって発生する熱膨張 に起因したロール偏心を推定する．圧延中はロール回転 数が高くなることから, 計算負荷の軽减を考慮して各口 ールどとの偏心パラメータの推定は行なわず，偏心の影 響が大きいロール，たとえば，4段圧延機のバックアッ プロール（以下 BUR）の一回転分の圧延荷重変動デー 夕より偏心成分を上 BUR を基準にして推定し，それに 基づいて次回転にて压下を補償する. 以下に偏心成分推 定用のモデルを示す.

$k$ 番目のサンプリングパルスに同期して得られた偏心 による荷重変動は，次式で表わされる。

$$
\begin{aligned}
\Delta P_{e n}(k)= & \frac{M Q}{M+Q} \sum_{m=1}^{n} e_{B m} \cdot \sin \left(m \theta_{B}(k)+\phi_{B m}\right) \\
& +P_{0}(k)+\Delta P_{\varepsilon}(k)
\end{aligned}
$$

ここで, $e_{B m}:$ BURの $m$ 次偏心振幅

$\phi_{B m}:$ BUR の $m$ 次偏心初期位相角

$n: \mathrm{BUR}$ の高周波成分の次数

オフライン推定法と同様に, (7) 式は次式に変形され る.

$$
\begin{aligned}
\Delta P_{e n}(k)= & \sum_{m=1}^{n}\left(X_{m 1} \sin m \theta_{B}(k)+X_{m 2} \cos m \theta_{B}(k)\right) \\
& +P_{0}(k)+\Delta P_{\varepsilon}(k) \\
= & \boldsymbol{a}(k) \cdot x(k)+\Delta P_{\varepsilon}(k) \\
\text { ただし, } & \\
\boldsymbol{a}(k)= & \left(\sin \theta_{B}(k), \cos \theta_{B}(k), \cdots\right. \\
& \left.\sin \left(n \theta_{B}(k)\right), \cos \left(n \theta_{B}(k)\right), 1\right) \\
x= & \left(X_{1}|, \cdots,| X_{m}|, \cdots,| X_{n} \mid X_{0}\right)^{T} \\
X_{m}= & \left(X_{m 1}, X_{m 2}\right)^{T} \\
X_{m 1}= & \frac{M Q}{M+Q} e_{B m} \cos \phi_{B m} \\
X_{m 2}= & \frac{M Q}{M+Q} e_{B m} \sin \phi_{B m} \\
X_{0}= & P_{0}(k)
\end{aligned}
$$

よって，(8) 式に基づき，逐次推定法によって偏心分 $X_{m 1}, X_{m 2}$ および荷重オフセット量 $X_{0}$ を時々刻々推定 できる. このように，本方法では，ロール一回転ごとに 偏心成分を推定することによって，ロール径差によって 生じる偏心波形の振幅と位相の変化に対応している.

\section{3 制御量の演算}

オフライン推定法によって推定された偏心パラメータ

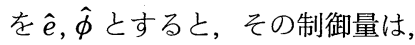

$$
\Delta u_{O F}(k)=\sum_{i=1}^{4} \sum_{m=1}^{n i} \hat{e}_{i m} \cdot \sin \left(m \theta_{i}(k)+\hat{\phi}_{i m}+\tau_{i m}\right)
$$

となる．ただし， $\tau_{i m}$ は各ロールの回転速度で決定され る圧下系の位相遅れ補償量である.

また, オンライン推定法によって推定された偏心成分 を $\hat{X}_{m 1}, \hat{X}_{m 2}$ とすると, ロール一回転ごとの制御であ るととから，積分型の制御となり，制御量は，

$$
\begin{aligned}
\Delta u_{O N}(k)= & \frac{M+Q}{M Q} \sum_{r}\left\{\sum_{m=1}^{n} \hat{X}_{m 1} \sin \left(m \theta_{B}(k)+\tau_{i m}\right)\right. \\
& \left.+\sum_{m=1}^{n} \hat{X}_{m 2} \cos \left(m \theta_{B}(k)+\tau_{i m}\right)\right\}
\end{aligned}
$$

となる．ただし， $\sum_{r}$ はロール一回転ごとに加算される 積分を表わす ${ }^{3}$.

したがって, 圧延中のロール偏心制御量は,

$$
\Delta u(k)=\alpha \cdot \Delta u_{O F}(k)+\beta \cdot \Delta u_{O N}(k)
$$

となる，ここで， $\alpha, \beta$ は制御ゲインである.

\section{4. 偏心パラメータの推定}

本ロール偏心制御システムでは，逐次推定法を用いて 偏心パラメータを推定している．以下では，基本となる 逐次型最小自乗推定, 平方根フィルタによる推定計算の 安定化, 指数荷重型最小自乗法による推定精度の向上お よび，パラメータの収束判定方法などについて述べる. 


\section{1 基本アルゴリズム}

（5）式，あるいは（9）式に基づいて逐次形パラメータ 推定の基本アルゴリズムを設定すると，(13）式となる?

$$
\begin{aligned}
\hat{x}(k+1)= & \hat{x}(k)+\boldsymbol{g}(k+1)\left(\Delta P_{e}(k+1)\right. \\
& -\boldsymbol{a}(k+1) \cdot \hat{x}(k)) \\
\boldsymbol{g}(k+1)= & \frac{B(k) \cdot \boldsymbol{a}^{T}(k+1)}{\lambda_{1}+\mathbf{a}(\mathrm{k}+1) B(k) \boldsymbol{a}^{T}(k+1)} \\
B(k+1)= & \{I-\boldsymbol{g}(k+1) \cdot \boldsymbol{a}(\boldsymbol{k}+\mathbf{1})\} \cdot \boldsymbol{B}(\boldsymbol{k})
\end{aligned}
$$

ここで,

$$
\begin{aligned}
& \Delta P_{e}(k)=\begin{array}{l}
\Delta P_{e f}: \text { オフライン推定法 } \\
\Delta P_{e n}: \text { オンライン推定法 }
\end{array} \\
& \hat{x}(k): x(k) \text { の推定ベクトル } \\
& B(k) \text { : 誤差共分散行列 } \\
& \boldsymbol{g}(k) \text { : 推定誤差を修正するゲインベクトル }
\end{aligned}
$$

4 段圧延機の場合 $\hat{x}(k)$ は，オフライン推定法では, $2 \sum_{i=1}^{4} n i+1$ 次元ベクトル, オンライン推定法では $2 n+1$ 次元ベクトルとなる．また， $\lambda_{1}$ は，最小自乗推定と力 ルマンフィルタとの互換性を保つ設定パラメータであり, $\lambda_{1}=1$ と設定すると最小自乗推定となり， $\lambda_{1}=$ 観測/ イズの分散と設定すると, カルマンフィルタのアルゴリ ズムと等価となる?.

\section{2 平方根フィルタの応用}

上記の基本アルゴリズムを用いて偏心パラメータの 推定シミュレーションを行なったとてろ, 推定值が発散 した. てれは，推定計算を単精度で行なっていたために 桁落ちが怙き, 収束の十分条件である誤差共分散行列 $B(k)$ の非負正定值性が満足されていないためであった. 乙の問題を解決するには倍精度演算を用いる方法がある が，計算負荷が過大となりオンライン制御に適さない。 そこで, Potter ${ }^{8}$ の平方根フィルタを応用して誤差共分 散行列の非負正定值性を保証した.

平方根フィル夕の考え方は, 誤差共分散行列をその積 が負定にならないてとが保証されている平方根行列に分 解し，数值的に安定なアルゴリズムに置き換えることに ある. 具体的な展開を以下に示す.

誤差共分散行列 $B(k)$ を，平方根行列 $S(k)$ を用いて 次式の上うに分解する.

$$
B(k)=S(k) \cdot S^{T}(k)
$$

(13) 式の関係より,

$$
\begin{aligned}
B(k+1) & =B(k)-\boldsymbol{g}(k+1) \cdot \boldsymbol{a}(k+1) \cdot B(k) \\
= & B(k)-\frac{B(k) \boldsymbol{a}^{T}(k+1) \boldsymbol{a}(k+1) \cdot B(k)}{\lambda_{1}+\boldsymbol{a}(k+1) B(k) \boldsymbol{a}^{T}(k+1)} \\
= & S(k)\left\{I-Z(k+1) \cdot \boldsymbol{f}(k+1) \boldsymbol{f}^{T}(k+1)\right\} S^{T}(k)
\end{aligned}
$$

ただし

$$
\begin{aligned}
\boldsymbol{f}(k+1) & =S^{T}(k) \cdot \boldsymbol{a}^{T}(k+1) \\
Z(k+1) & =\frac{1}{\lambda_{1}+\boldsymbol{a}(k+1) \cdot B(k) \cdot \boldsymbol{a}^{T}(k+1)} \\
& =\frac{1}{\lambda_{1}+\boldsymbol{f}^{T}(k+1) \cdot \boldsymbol{f}(k+1)}
\end{aligned}
$$

ここで， $B(k+1)$ を平方根行列に分解し，その逐次 解を求めることを考える．まず，(15）式の\{ \}の部分 に正の未定定数 $\gamma(k+1)$ を導入し, 下式のように分解 する.

$$
\begin{aligned}
I- & Z(k+1) \boldsymbol{f}(k+1) \boldsymbol{f}^{T}(k+1) \\
= & \left\{I-\gamma(k+1) Z(k+1) \boldsymbol{f}(k+1) \boldsymbol{f}^{T}(k+1)\right\} \\
& \times\left\{I-\gamma(k+1) Z(k+1) \boldsymbol{f}(k+1) \boldsymbol{f}^{T}(k+1)\right\}
\end{aligned}
$$

本式が成立するように $\gamma(k+1)$ を定めると次式となる.

$$
\gamma(k+1)=\frac{1}{1+\sqrt{\lambda_{1} Z(k+1)}}
$$

乙の導出の詳細を, 付録 1 亿示す.

したがって, (14)，(15)，(17)，(18) 式より，B(k+1) の平方根行列 $S(k+1)$ は下式により, 逐次的に計算で きる.

$S(k+1)$

$$
=S(k)-Z(k+1) \gamma(k+1) S(k) \boldsymbol{f}(k+1) \boldsymbol{f}^{T}(k+1)
$$

また，乙のとき，(16) 式より, ゲインベクトル $\boldsymbol{g}(k+1)$ は,

$$
\boldsymbol{g}(k+1)=Z(k+1) \cdot S(k) \cdot \boldsymbol{f}(k+1)
$$

\section{で表わされる.}

よって, 基本アルゴリズム (13) 式のうち, 䛊差共分 散行列 $B$ とゲインベクトル $\boldsymbol{g}$ を(16), (18), (19) 执よ び，(20）式に置き換えて逐次的に解くてとにより，偏 心パラメータを安定して計算できる.

\section{3 指数荷重型最小自乗法の適用}

Fig. 5 にロール偏心による荷重変動データ（実測）を 示す. 本図からわかるように, 荷重オフセット量は一定 ではなく，ゆるやかな変動を持つ場合がある．乙のデー 夕列に対して上記のアルゴリズムを用いると, 荷重オフ セット量の推定精度が悪化する。乙れは, 荷重オフセッ 卜量が変動するにあかかわらず, 誤差共分散行列が収束 してしまうためである. その結果, 推定パラメータが収 束してしまうために荷重オフセット量の変動に追従でき ないばかりでなく，偏心パラメータの推定精度の悪化を 招いている. そてで, 指数荷重形最小自乗法, 10 を適用 するととによって, 推定精度を向上させた. 


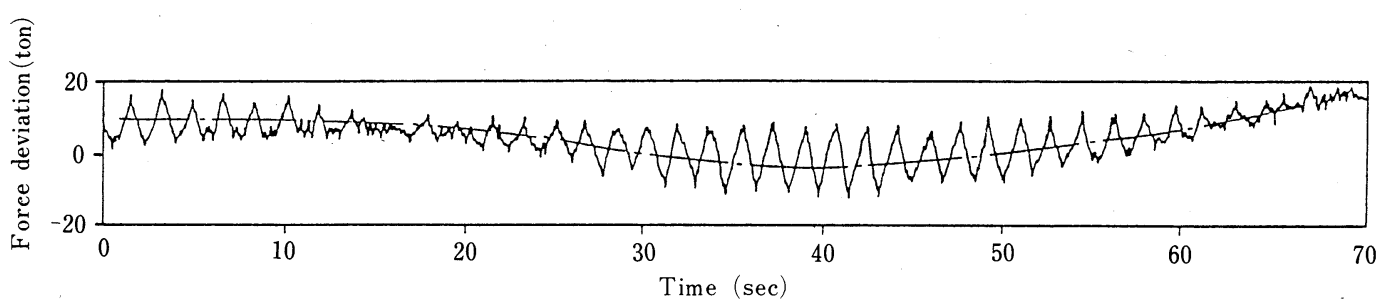

Fig. 5 Actual force deviation due to roll eccentricity with gradual offset

すなわち，指数荷重形最小自乗法では，評価指標とし $\tau$,

$$
\begin{aligned}
& J=\sum_{m-1}^{k} \delta^{k-m} \cdot\left\{\Delta P_{e}(m)-\boldsymbol{a}(m) \cdot \hat{x}(m)\right\}^{2} \\
& \text { （ただし， } \delta(<1.0) \text { は，重み係数） }
\end{aligned}
$$

を導入することにより，誤差共分散行列の急峻な減少を 防止する. 指数荷重形最小自乗法を逐次型に展開すると, 基本アルゴリズムにおいて，ゲインベクトル $\boldsymbol{g}$ ，および 共分散行列 $B$ が次式となる ${ }^{10}$.

$$
\begin{aligned}
& \boldsymbol{g}(k+1)=\frac{B(k) \cdot \boldsymbol{a}^{T}(k+1)}{\delta+\boldsymbol{a}(k+1) B(k) \boldsymbol{a}^{T}(k+1)} \\
& B(k+1)=\frac{1}{\delta}\{I-\boldsymbol{g}(k+1) \cdot \boldsymbol{a}(k+1)\} \cdot B(k)
\end{aligned}
$$

\section{4 パラメータ推定アルゴリズムの汎用化}

以上の検討結果から，本システムでは，最小自乗推 定, カルマンフィルタ，打よび指数荷重形最小自乗法 をそれぞれの特徴に応じて適用できるシステムとした。 また，三つの方法を合理的に使い分けることを考慮し， 推定アルゴリズムを汎用化した. すなわち，同一の推定 式で偏心パラメータの推定ができるように， $\lambda_{1}$ に加え て新たに $\lambda_{2}, \lambda_{3}$ を導入した ${ }^{11}$. 汎用化したアルゴリズム を以下に示し， $\lambda$ パラメータの設定方法を Table 1 に 示す. また，本アルゴリズムの導出の詳細を付録 2 亿示 于.

$$
\begin{aligned}
\hat{x}(k+1)= & \hat{x}(k) \\
& +\boldsymbol{g}(k+1) \cdot\left\{\Delta P_{e}(k+1)-\boldsymbol{a}(k) \cdot \hat{x}(k)\right\} \\
\boldsymbol{g}(k+1)= & \frac{S(k) \cdot \boldsymbol{f}(k+1)}{\lambda_{1}+\boldsymbol{f}^{T}(k+1) \cdot \boldsymbol{f}(k+1)} \\
S(k+1)= & \frac{1}{\sqrt{\lambda_{2}}}\left\{S(k)-\frac{Z(k+1)}{1+\sqrt{\lambda_{2} / \lambda_{3} \cdot Z(k+1)}}\right. \\
& \left.\times S(k) \cdot \boldsymbol{f}(k+1) \boldsymbol{f}^{T}(k+1)\right\} \\
\text { ただし, } & S^{T}(k) \cdot \boldsymbol{a}^{T}(k+1) \\
\boldsymbol{f}(k+1) & \frac{1}{\lambda_{2} / \lambda_{3}+\boldsymbol{f}^{T}(k+1) \boldsymbol{f}(k+1)}
\end{aligned}
$$

Table 1 Classification of recursive estimation for roll eccentricity control

\begin{tabular}{|c|c|}
\hline Setting parameters & Estimation algorithm \\
\hline$\lambda_{1}=\lambda_{2}=\lambda_{3}=1.0$ & Least square estimation \\
\hline$\lambda_{1}=\frac{1}{\lambda_{3}}=\sigma_{e}^{2}$ & kalman filter \\
$\lambda_{2}=1.0$ & $\left(\sigma_{e}^{2}:\right.$ variance of $\left.\Delta P \varepsilon\right)$ \\
\hline$\lambda_{1}=\lambda_{2}=\delta$ & Exponentially weighted \\
$\lambda_{3}=1$ & least square estimation \\
& $(0.995<\delta<0.999)$ \\
\hline
\end{tabular}

\section{5 収束性の判定}

オフライン推定法では, キスロール回転状態で偏心パ ラメータを推定するので，その間，圧延を行なうことが できない，そこで，推定時間を短縮するために，推定パ ラメータの収束性を自動的に判定し，推定を終了するシ ステムとした，収束性を判定する方法を以下に示す。

逐次推定法では, パラメータの収束と共に推定誤差の 共分散が減少してゆく，共分散の減少は誤差共分散行列 $B(k)$ の固有值の減少によって定量化されるが，個々の 固有値を求めるには固有值演算用のソフトウエアを用意 する必要があり，逐次推定中に演算を行なうことは計算 負荷が過大となり，現実的ではない.

いっぽう， $B(k)$ が正定值行列であることから，すべ ての固有値が正である. したがって, 全固有值の合計, すなわち， $B(k)$ のトレースの逐次計算値を監視するて とによって，推定パラメータの収束性を判定するてとが 可能である.

収束の判定条件を次式に示す.

$$
\operatorname{tr}(B(k))<\Gamma
$$

ただし， $\Gamma$ は, 収束判定のためのしきい值であり, パ ラメータの推定精度維持之圧延停止時間の短縮化を勘案 して, シミュレーションと実機テストの結果により, 適 切な值を決定した。

\section{5. シミュレーションによる考察}

冷延タンデムミルの No.1 スタンドを想定し，ロー 
Table 2 Simulation conditions for roll eccentricity control

\begin{tabular}{|c|c|c|c|c|c|}
\hline \multicolumn{2}{|c|}{$\begin{array}{l}\text { Items } \\
\text { Roll }\end{array}$} & $\begin{array}{l}\text { Top } \\
\text { Back-up roll }\end{array}$ & $\begin{array}{l}\text { Bottom } \\
\text { Back-up roll }\end{array}$ & $\begin{array}{l}\text { Top } \\
\text { Back roll }\end{array}$ & $\begin{array}{l}\text { Bottom } \\
\text { Back roll }\end{array}$ \\
\hline \multirow{2}{*}{$\begin{array}{l}\text { Fig } \\
\qquad 6 \sim 12\end{array}$} & $\begin{array}{c}\text { Amplitude } \\
{[\mu]}\end{array}$ & 5.0 & 3.0 & 1.0 & 2.0 \\
\hline & $\begin{array}{l}\text { Phase } \\
\text { angle [deg] }\end{array}$ & -90 & 90 & 45 & 45 \\
\hline$\underset{13,14}{\mathrm{Fig}}$ & $\begin{array}{c}\text { Amplitude } \\
{[\mu]}\end{array}$ & 5.0 & 4.0 & 2.0 & 3.0 \\
\hline \multicolumn{2}{|c|}{$\begin{array}{l}\text { Roll diameter } \\
{[\mathrm{mm}]}\end{array}$} & 1420.0 & 1380.0 & 522.0 & 544.0 \\
\hline
\end{tabular}

ル偏心の推定および，制御シミュレーションなど，各種 のシミュレーションを行なった. その方法を以下に述べ る.

(1) 制御対象として, Fig. 2.2 のゲージメータ AGCを 備えた 4 段圧延機を想定した.

(2) 偏心によるロール表面の変動として, バックアップ ロールとワークロールの偏心を正弦波で近似し（基 本周波数成分のみ), 白色ノイズを付加した信号を(A) の位置に加える. 想定した偏心量や初期位相角など の条件を Table 2 に示す.

(3)オフライン推定法では, 荷重変動や, 角度データを 用いて偏心量の推定を行なう。 その結果を基にして （10）式で制御量を計算し，Bの位置に入力して制御 シミュレーションを行なう.

(4) オンライン推定法では, 荷重変動や, 角度データを用 いて偏心波形の推定を行ないながら，(11）式で計算 された制御量を(B)位置に入力して制御シミュレー ションを行なう.

シミュレーション結果の説明と考察を次に示す.

（1）シミュレーションにより偏心による荷重変動を計算 した結果を Fig. 6 に示す（ただし， $P_{0}=0.0$ ）。 ワ

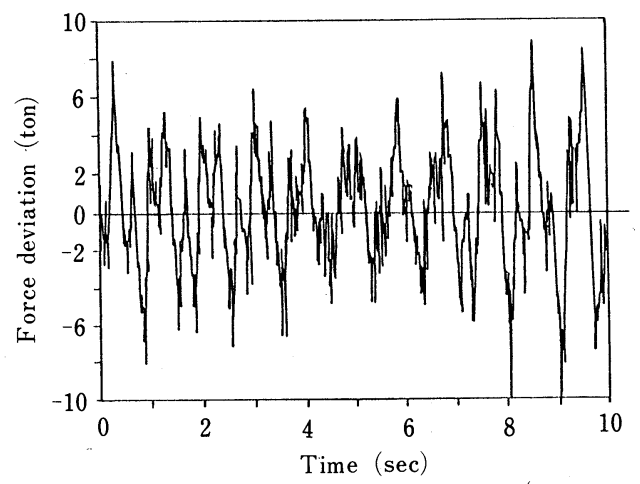

Fig. 6 Simulated force deviation due to roll eccentricity
ークロール偏心の影響は, ノイズ $\Delta P_{\varepsilon}(k)$ にって 明確には判別できない.

(2) 本データに対してオフライン推定法を適用し, 各口 一ルの偏心量 $(e)$ と位相量 $(\phi)$ を推定した結果を Fig. 7 に示す. とあに推定開始から, 約 8 秒で真值（図中 の破線で示した設定值）に収束していることがわかる. また, 䛊差共分散行列のトレースの減少をFig. 8 に 示す.トレースの值は安定して減少するとともに, 収 束判定のしきい值を, この例では， $\Gamma=0.05$ とすれ ば良いことがわかる. 推定された結果を用いて制御を 行なったときの荷重変動を Fig. 9 亿示す. 制御中で は，ほぼノイズ成分のみの変動であることがわかる.

(3) 逐次型最小自乗推定とカルマンフィルタによるパラ メー夕推定と誤差共分散行列の収束性を比較するため に, シミュレーションを行なった. その結果を Fig. 10.1, Fig.10.2 に示す. ここでは, 偏心による荷重変 動と, BUR の偏心量の推定結果を示している.（ただ し, 推定結果の初期の部分は紙面の都合で一部を飽和 させている. ) また, 収束判定基準 $(\Gamma)$ を $\Gamma=0.1$ と 設定し,（24）式の条件で推定を終了させている. Fig. 10.1 では，観測ノイズの大きい場合としてノイズの 分散 $\left(\sigma_{e}^{2}\right)$ を $25\left[\right.$ ton $\left.^{2}\right]$ としている.

カルマンフィルタでは, パラメータ収束後の適切な 時間で推定が終了しているのに対し，最小自乗推定で は，パラメータが収束する前に推定が終了している. 一方, Fig. 10.2 では, 観測ノイズの小さい場合とし て $\sigma_{e}^{2}=0.06\left[\right.$ ton $\left.^{2}\right]$ としており, カルマンフィルタで は, 短時間で推定を終えているのに対し, 最小自乗推 定では, パラメータ収束後も推定を続けている.

一定変数を逐次型最小自乗推定で推定する場合, 力 ルマンフィルタにおいてシステムノイズがなく, $\lambda_{1}=1$ とした場合に等価である ${ }^{10}$. したがって, Fig. 10 の結果からもわかるように, 推定パラメータの収 束過程は, 推定初期を除いて同等である. 一方, 誤差 


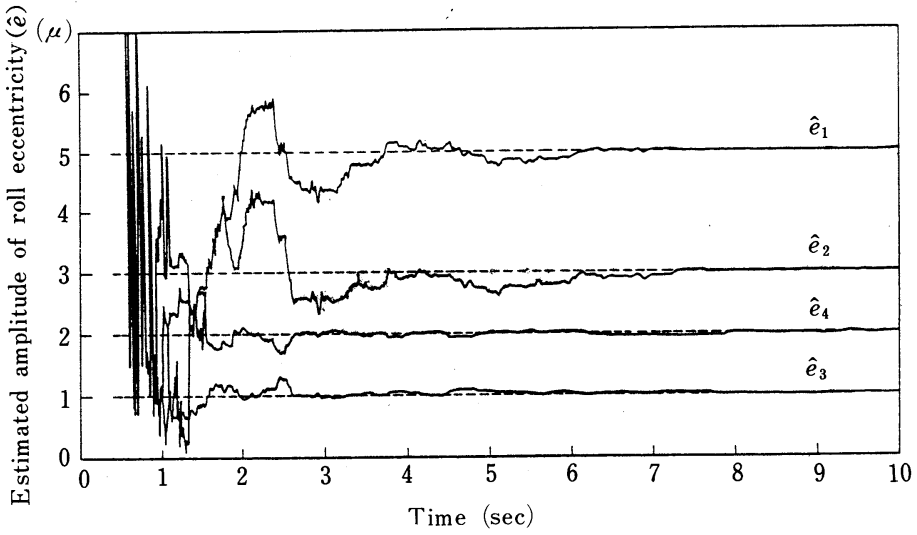

Fig. 7.1 Estimated amplitude by the "Off-line estimation method"

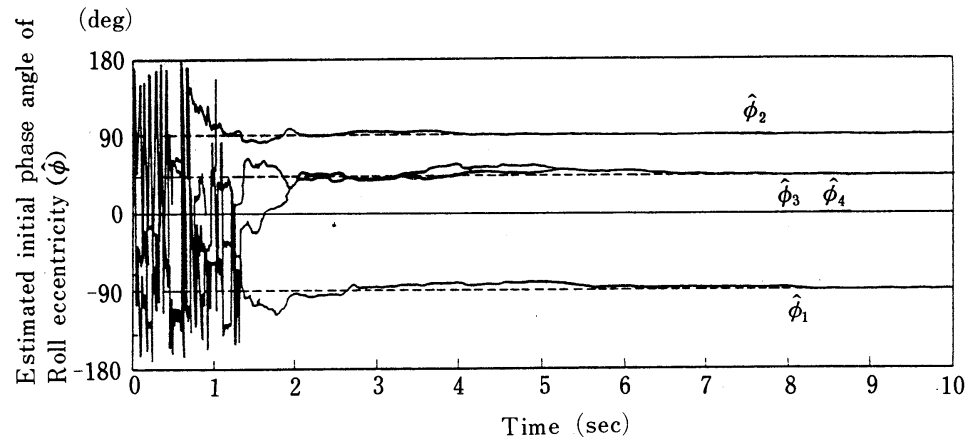

Fig. 7.2 Estimated initial phase angle by the "Off-line estimation method"
カルマンフィルタとして機能させて, パラメータ推定の高精度化と推定時間 の短縮を図る.

一方，ノイズの分散值がわからない 場合には，逐次型最小自乗推定として 機能させる. このとき, カルマンフィ ルタを適用した場合より推定時間がか かる場合があるが，推定精度を保証す るために， $\Gamma$ を観測ノイズの分散が 予想される最大の值をとる場合を想定 して設定する.

（4）オンライン推定法によって偏心成分 を推定した結果を Fig. 11 に示す. オ ンライン推定法では, BURの 1 回転 ごとに（9）式に従って $X_{m 1}, X_{m 2}$ を 推定し，次回転では，その結果に基ゔ いて制御量を計算する.さらに，その 制御結果を制御残差と考え，推定と制 御をくりかえす。したがって，制御量 は各回転における $X_{m 1}, X_{m 2}$ の収束 值を（11）式に代入し，その積分值に 基づいて決定される. 本図では， $X_{m 1}$, すなわち，（8）式における sine成分 の推定結果とその積分結果の推移を示 している. sine 成分は, 各回転中に 収束しており，その収束值の積分值が 安定して推移している. ての積分值が 1 回転中で変化 しないのは，積分を上 BUR の 1 回転ごと（基準パル スごと）に行なっているためである．また，積分值が ゆるやかに変化するのは, ロール系差によって偏心の 振幅や位相が変化するのに対応している．また，オン ライン推定法による制御結果を Fig.12 に示す. BUR の偏心のみを制御するモデルであるために，制御中で あワークロール (WR) 偏心の影響が残り, Fig. 9 の

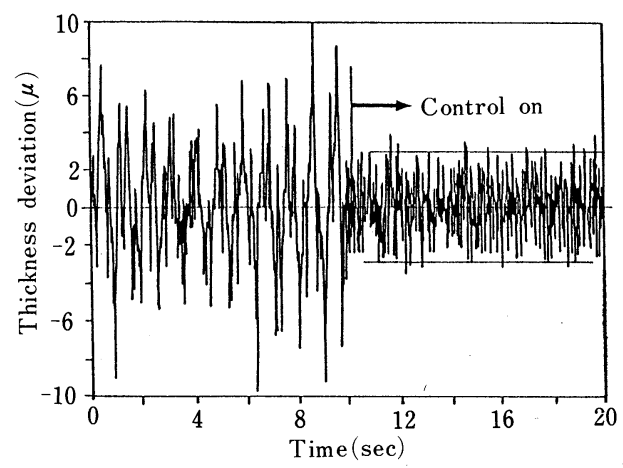

Fig. 9 Decrease of thickness deviation due to roll eccentricity by the "Off-line estimation method" かじめ，計算あるいは観測してわかっている場合には， 


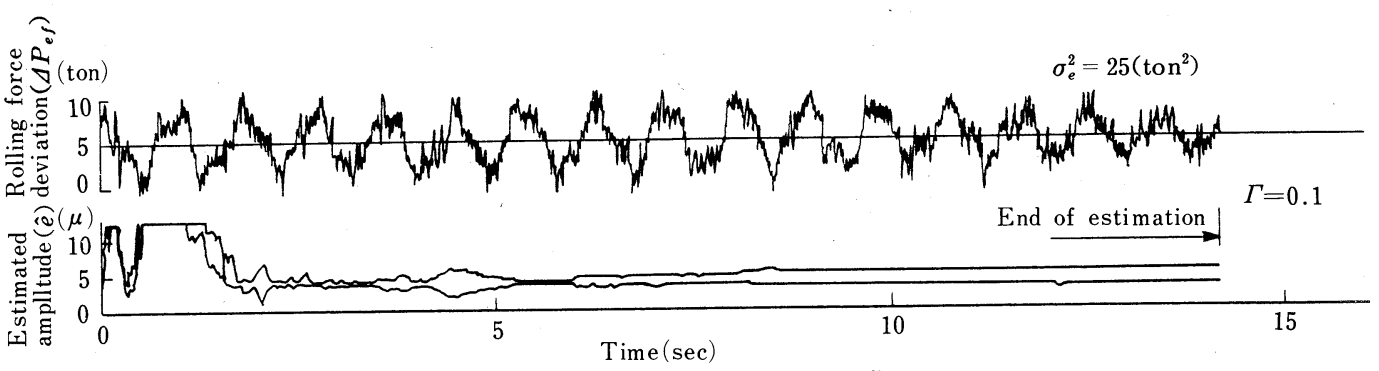

(a) Estimated result by Kalman filter

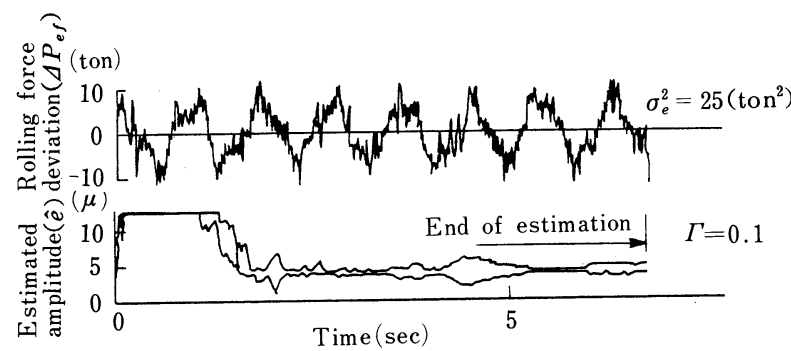

(b) Estimated result by least square estimation

Fig. 10.1 Comparison between Kalman filter and least square estimation $\left(\begin{array}{c}\sigma_{e}^{2}=25 \\ \left(\operatorname{ton}^{2}\right)\end{array}\right)$

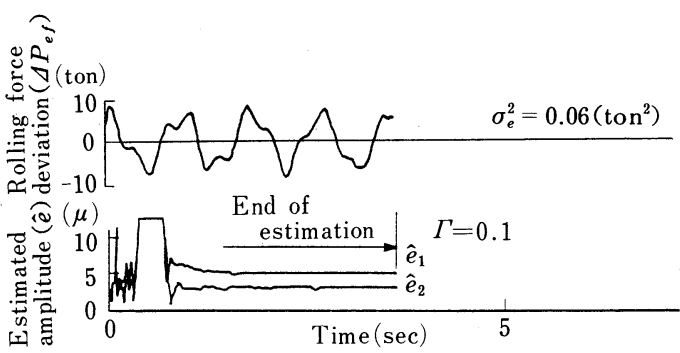

(a) Estimated result by Kalman filter

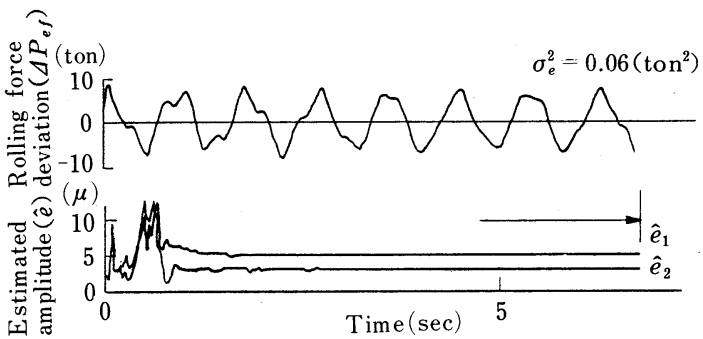

(b) Estimated result by least square estimation

Fig. 10.2 Comparison between Kalman filter and least square estimation $\left(\sigma_{e}^{2}=0.06\right.$ ton $\left.^{2}\right)$ )

オフライン推定法の結果に比べて荷重変動が大きくなっ ているととがわかる。

(5) オフライン推定法による荷重オフセット量の推定結 果をFig. 13 亿示す. 本図では, 指数荷重型最小自乗 法を適用した場合 $(\delta=0.997)$ と最小自乗推定の場合

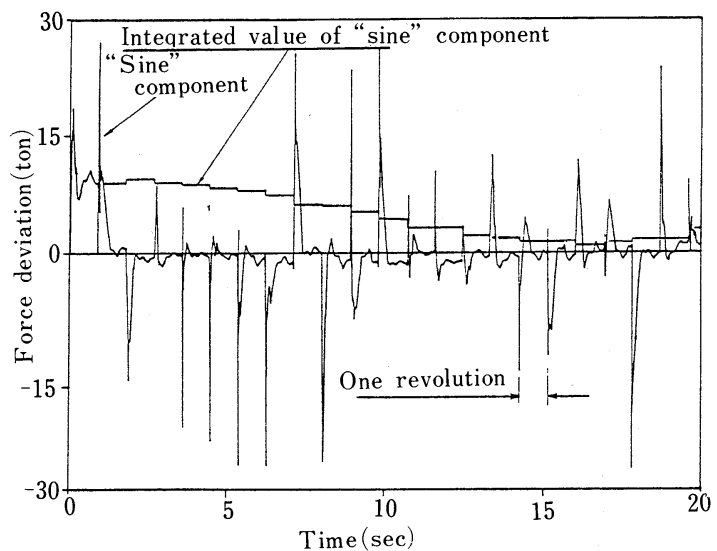

Fig. 11 Estimated "sine" component and its integrated value in the "On-line estimation method"

を比較して示している. また, 本シミュレーションで は, 荷重オフセット量を,

$$
P_{o f}(t)=34 \times \sin \left(\frac{2 \pi}{34} t+\pi\right) \quad \text { [ton] }
$$

としている. (Fig.13 の破線で示す.)

指数荷重型最小自乗法を用いる方が，オフセット量 をより精度良く推定しているてとがわかる，また，本 方法による偏心パラメータのうち, 偏心量の推定結果 を最小自乗推定の場合と比較して Fig. 14 亿示す. 本 方法を適用した方が, 振動が小さく, より速く推定で きるととがわかる。 


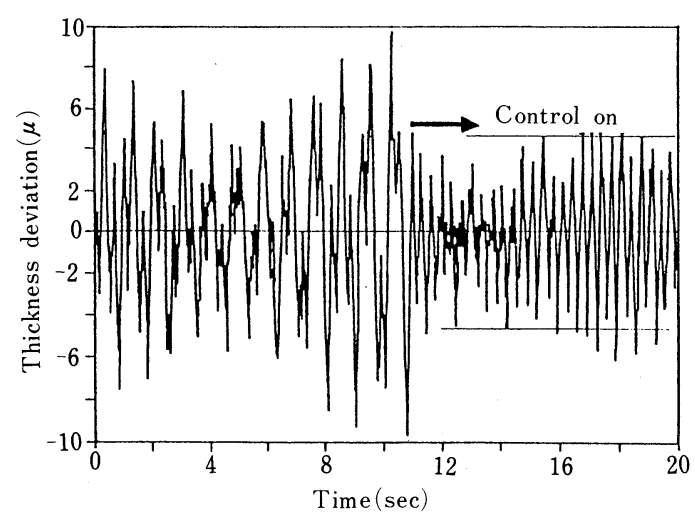

Fig. 12 Decrease of thickness deviation due to roll eccentricity by the "On-line estimation method

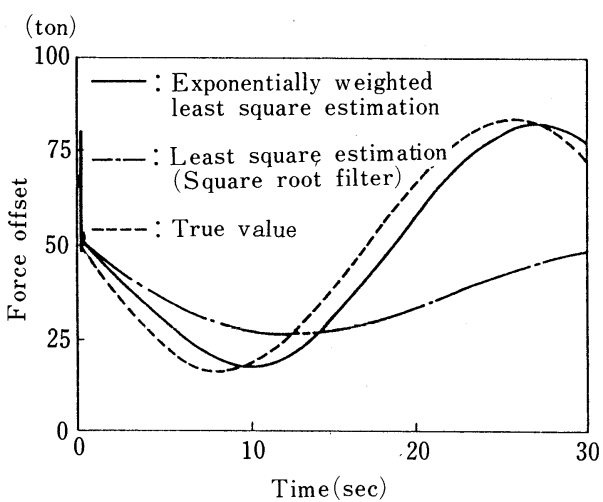

Fig. 13 Estimated force offset by exponentially weighted least square estimation compared with least square estimation (square roof filter)

本方法は重み付き最小自乗推定と等価であ り，(21）式に扔いて $k$ を現在時刻とすると, $\delta^{k-m}$ は過去になるほど小さくなる重みであ り，過去值の推定值への寄与を小さくする働 きがある. この重み付けの効果で，ゆっくり と変動するパラメータの推定にあ適用でき $ろ^{10}$. 本システムでは，荷重オフセット量が 変化するロール熱上げ時など, 荷重の平均值 がゆっくり变動する場合に適用する.

\section{6. 実機適用結果}

冷延タンデムミルNo.1 スタンドに適用し た結果を以下に述べる．制御システムの概略を Fig. 15 に示す。ロール偏心制御は PLC（プ ログラマブルロジックコントローラ）で実現さ れており，材料塑性係数などのパラメー夕は, 圧延コイルでとに上位のプロセスコンピュータ から伝送される，また，本タンデムミルでは，

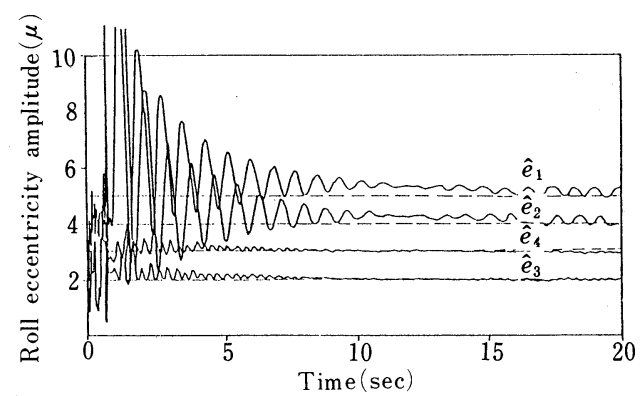

Fig. 14.1 Estimated amplitude by least square estimation

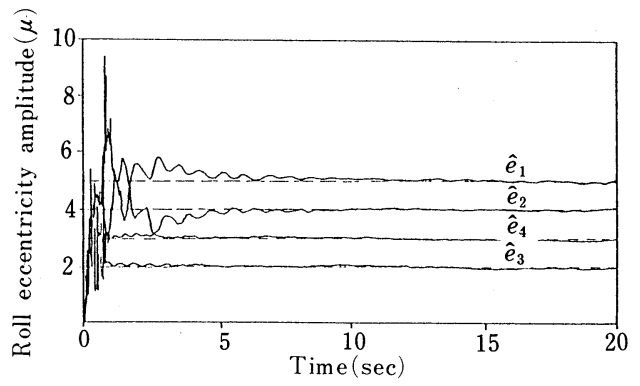

Fig. 14.2 Estimated amplitude by exponentially weighted least square estimation

No.2 スタンド出側, No. 5 スタンド出側に X 線板厚計 が設置されて抢り，偏心制御の結果は，No.1.スタンド の圧延荷重変動とてれらの板厚計データによって確認さ れる.また，以下に示す各実験時の諸条件を, Table 3 に示す.

（1）オフライン推定法の実機適用結果を Fig.16, Fig.17

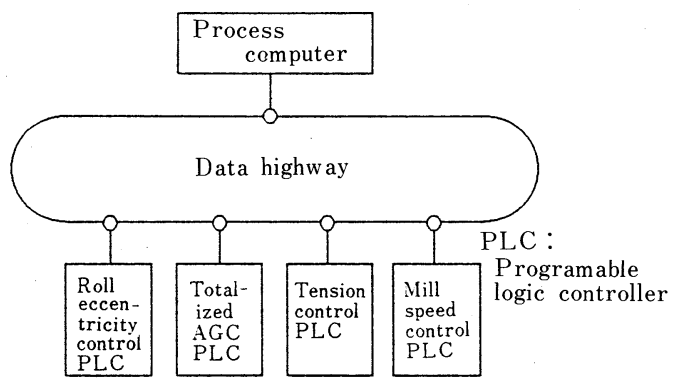

Rolling direction $\Longrightarrow$

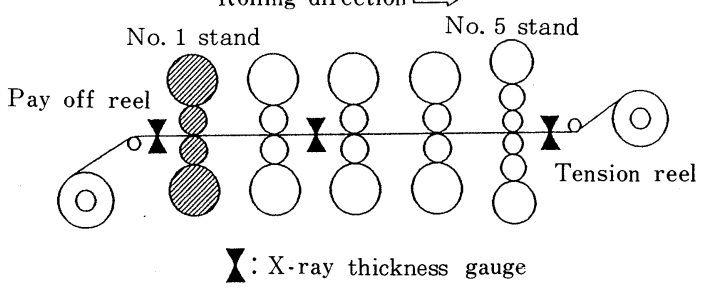

Fig. 15 Outline of tandem cold mill and its computer control system 
Table 3 Conditions for rolleccentricity contrn actual rolling

\begin{tabular}{|c|c|c|c|c|}
\hline $\begin{array}{l}\text { Figure } \\
\text { number }\end{array}$ & Fig. 16,17 & Fig. 18 & \multicolumn{2}{|c|}{ Fig. 20} \\
\hline $\begin{array}{l}\text { Estimation } \\
\text { method }\end{array}$ & off-line & on-line & off-line & on $=$ line \\
\hline Algorithm & kalman filter & $\begin{array}{l}\text { Least square } \\
\text { estimation }\end{array}$ & $\begin{array}{l}\text { E. W. } \\
\text { L. S. E. }\end{array}$ & $\begin{array}{l}\text { Least square } \\
\text { estimation }\end{array}$ \\
\hline Parameters & $\begin{aligned} \lambda_{1} & =2.0 \\
\lambda_{2} & =1.0 \\
\lambda_{3} & =0.5 \\
r & =0.05\end{aligned}$ & $\begin{array}{l}\lambda_{1}=1.0 \\
\lambda_{2}=1.0 \\
\lambda_{3}=1.0\end{array}$ & $\begin{aligned} \lambda_{1} & =.997 \\
\lambda_{2} & =.997 \\
\lambda_{3} & =1.0 \\
r & =.01\end{aligned}$ & $\begin{array}{l}\lambda_{1}=1.0 \\
\lambda_{2}=1.0 \\
\lambda_{3}=1.0\end{array}$ \\
\hline Dimension & $n 1=n 2=2$, & \multicolumn{3}{|c|}{$n 3=n 4=1($ off - line $)=2($ on - line $)$} \\
\hline $\begin{array}{l}\text { Back-up roll } \\
\text { diameter }[\mathrm{mm}]\end{array}$ & $\begin{array}{l}\text { TBR: } 1490.0 \\
\text { BBR: } 1497.2\end{array}$ & $\begin{array}{l}\text { TBR: } 1521.4 \\
\text { BBR: } 1520.1\end{array}$ & $\begin{array}{l}\text { TBR } \\
\text { BBR }\end{array}$ & $\begin{array}{l}480.9 \\
477.9\end{array}$ \\
\hline
\end{tabular}

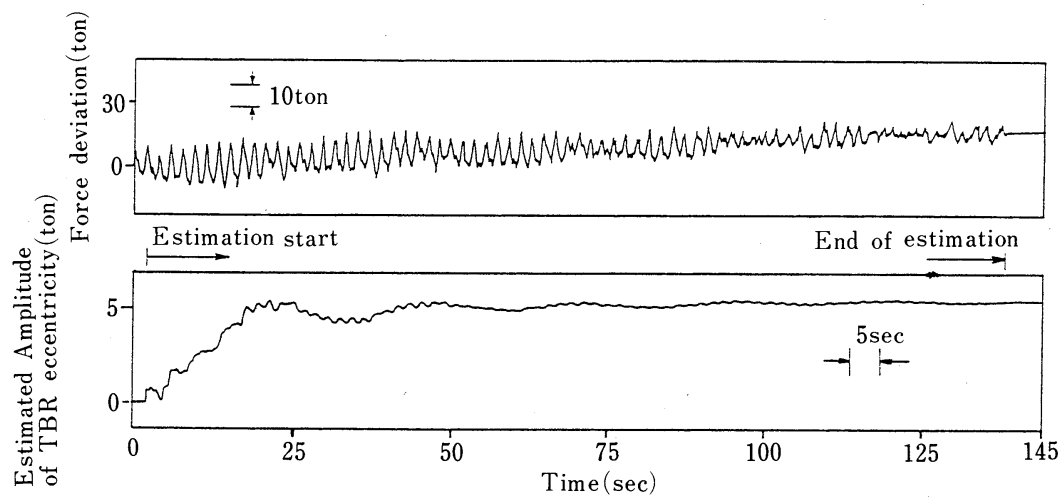

Fig. 16 Estimated resut of eccentricity amplitude by the "Off-line estimation method" for actual rolling

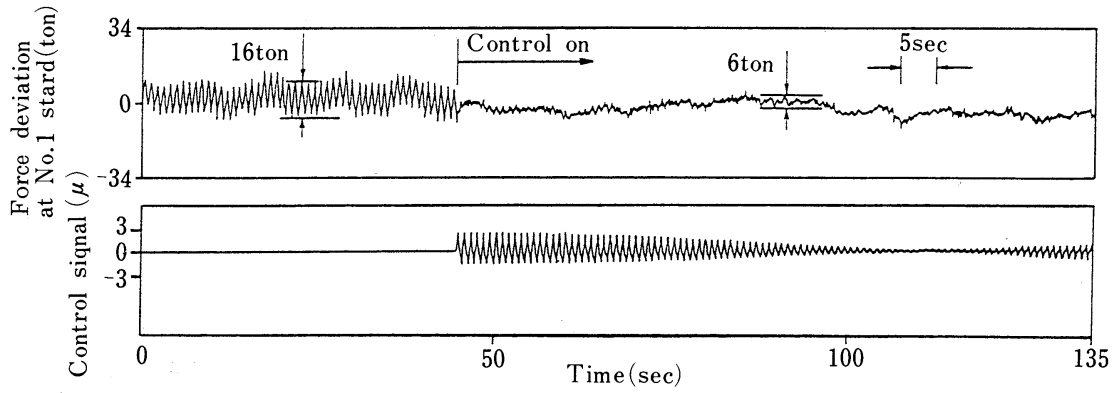

Fig. 17 Applied resut of the "Off-line estimation method" for actual rolling (Roll contact mode)

に示す. Fig.16では, 推定時の荷重変動と上バック アップロールの偏心量の推定結果を示している. パラメ 一タが安定して推移し, 収束している. こてでは, パラ メータ推定にカルマンフィルタを用いた. ノイズの分 散については，あらかじめ推定計算し，その結果から $\lambda_{1}=2.0$ と設定した. $\Gamma$ については，小さい值をとる
ほうが高精度の推定となるが，推定に時間がかかる. そこで, シミュレーションの結果 $(\Gamma=0.1)$ を参考と して推定精度を重視し， $\Gamma=0.05$ と設定した。 この 結果, 適切な時間で推定が判定できていることがわか る. また，乙の推定結果に基づき，キスロールに掞い て制御した結果を Fig. 17 に示す. 偏心による荷重変 

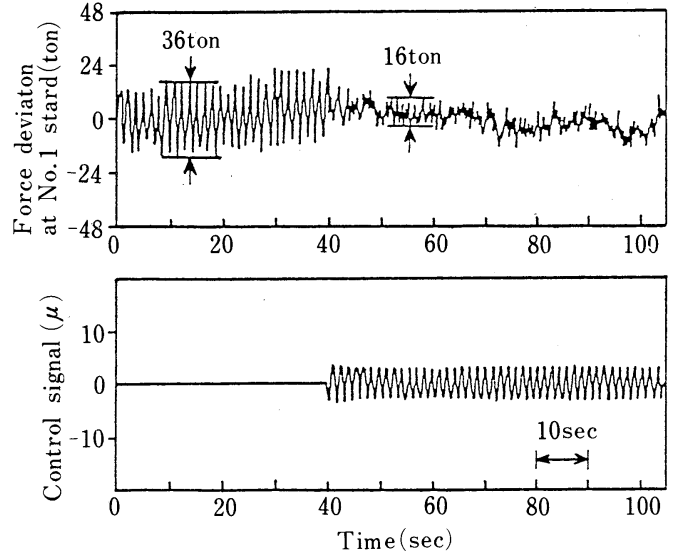

Fig. 18 Applied result of the "On-line estimation method" for actual rolling (Roll contact mode)

動 16 Ton が 6 Ton 以下に減少し, 偏心の影響が充 分に除去されている.

(2) キスロールに打いてオンライン推定法によって制御 を行なった結果を Fig. 18 に示す. 偏心による荷重変 動 36 Ton が 16 Ton 以下に減少し，バックアップロ ールの偏心の影響が除去されている.

(3) Fig. 19 に実圧延時に, No.1 スタンドの荷重デー 夕を周波数解析した結果を示す. Fig. 19 (a) には, 無制御時の周波数分析結果を示し, Fig. 19 (b) には オフライン推定法による制御時の結果を示している.

BUR とWR の偏心による荷重変動が $1 / 2$ 以 下に制御されている. また，Fig. 19 (c) に はオンライン推定法による制御時の周波数分 析結果を示す.WR の偏心の影響は除去され ないが, BURについては偏心による荷重変 動が約 $35 \%$ 減少している. Fig. 19 (b) と (c) を比較すると, オフライン推定法による 制御の方が BUR 偏心の制御効果がまさって いる. これは,オフライン推定法の方が，口 一ル径差による偏心振幅と位相の変化を遅れ なくとらえるためと考えられる.

（4）実圧延時に，オフライン，执よびオンライ ン推定法を組み合わせて制御を行なった結果 を, Fig. 20 に示す. オフライン推定法では, 荷重オフセット量の変動があったため, 指数 荷重型最小自乗法を用いた。 $\lambda_{1}\left(\lambda_{2}\right)$ について は，事前の推定テストにより，荷重オフセッ 卜量の収束性がよい值として，0.997 を選ん だ. $\Gamma$ にいては，本方法が観測ノイズの 影響を考慮していないてとから推定精度を重 視し, $\Gamma=0.01$ と選んだ. 荷重変動の減少

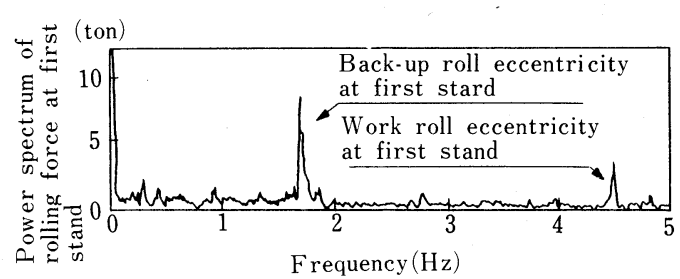

(a) Non-control

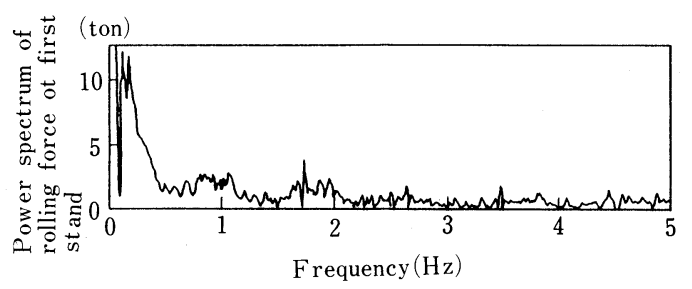

(b) Off-line estimation method

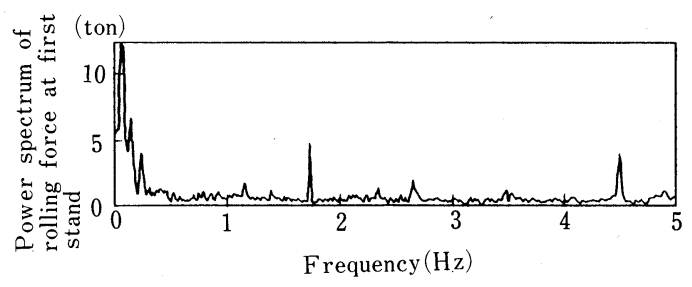

(c) On-line estimation method

Fig. 19 Frequency analysis of eccentricity control

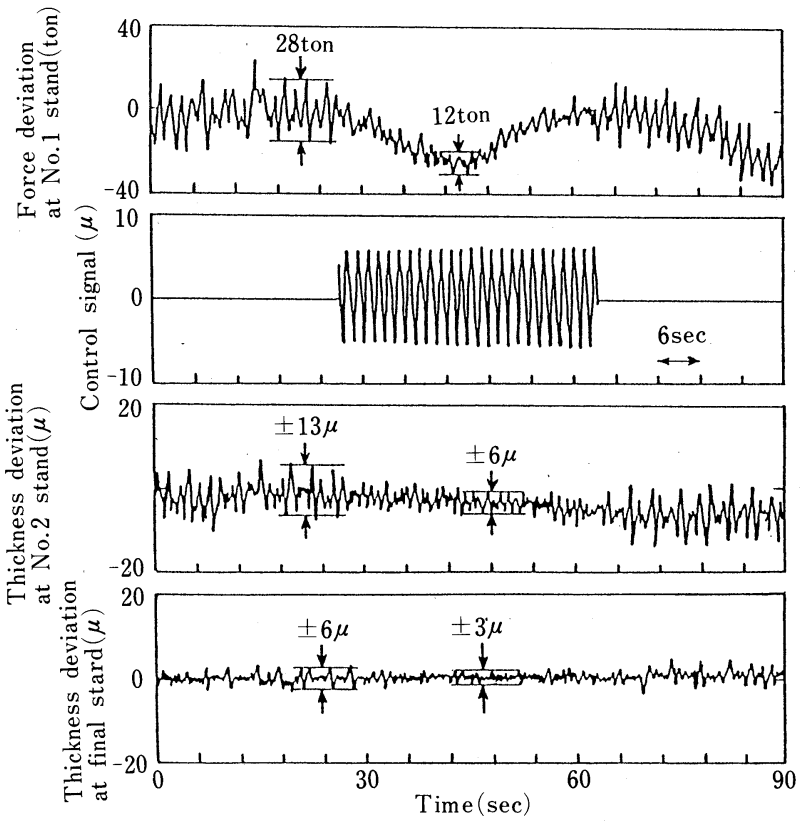

Fig. 20 Applied result of roll eccentricity control system for actual rolling (the "Off-line" \& "On-line" estimation method) 
と共に, 偏心による板厚変動が減少し, 最終製品板厚 (No. 5 スタンド出側) で, 約 $\pm 6 \mu$ が約 $\pm 3 \mu$ 以下に 制御されている. 噛み止め後, オフライン推定法のみ では偏心振幅が増大するのに対して，2方法を併用す るとほぼ同じ制御結果を得る。乙れは, 噛み止め時に ロールの熱的偏りによる付加的な偏心が発生し, オフ ライン推定法のみでは対応できないのに対し，2 方法 を併用することにより，ロール 1 回転中にパラメータ 推定ができることが最大の特徴であるオンライン推定 法の制御効果が表われたあのと考えられる.

\section{7.おわりに}

逐次推定法に基づくロール偏心の推定アルゴリズムを 開発し，偏心制御システムを構築した。 また，本システ ムを冷延実機に適用し，その効果を確認した．以下にそ の特徵之効果をま之めて示す.

本制御システムに打ける逐次推定アルゴリズムの特徵 は,

（1）数值演算上の誤差に起因する偏心パラメータ值の発 散を防止し, 収束性を保証するために平方根フィルタ を適用している.

(2) 観測雑音ノイズの分散があらかじめわかる場合には, カルマンフィルタの適用により, 推定精度の保証と推 定時間の短縮を図っている.

（3）ロールの熱膨張などに起因して荷重オフセット量や 偏心パラメータがゆるやかに変化する場合には，指数 荷重形最小自乗法として機能させ, 推定精度を向上さ せる.

制御システムとしての特徴は,

（1）ロール固有の幾何学的な偏心亡圧延中に発生する付 加的な偏心に対応するため, オフライン推定法とオン ライン推定法を組み合わせたシステムとしている.

(2) オフライン推定法では, 推定を効率的に実施するた めに, 誤差共分散行列の固有値の減少にともない, 偏 心パラメータの収束を自動的に判定する.

最後に, 冷延タンデムミルに適用した結果, ロール偏 心に起因する荷重変動および板厚変動が半減以下に減 少することが確認できた.

\section{参 考 文 献}

1) 高橋, 美板 : Gaugemeter AGC の進歩 : 塑性と加工, 16 巻, 168 号, pp. 25 31 (1975)

2) 北村, 能勢, 小西, 中田: 油圧圧下 AGC の最適ゲイン設 計 ; システム制御情報学会誌, 2 巻, 5 号, pp. 147〜154 (1989)

3) 今井, 鈴木: 圧延におけるロールの偏心影響除去制御装置 (FARE) の実用化; 石川島播磨技法, 13 巻, 2 号, pp. 189 198 (1973)
4) 大井, 近藤 : ロール偏心波形の同定; 第 29 回システムと 制御研究発表講演会予行集, pp. 21 22 (1985)

5) 橋本, 阿部, 葉山, 花浦: 圧延機口ール偏心制御装置 (MARECS) の開発と実用化; 三菱重工技法, 18 巻, 2 号, pp. 248 253 (1981)

6) B. Schmit : Aufbau der Regelkreise Einer Modernen Zahlregerung ; Stahl und Eisen, Vol. 97, No. 9, pp.450 455 (1977)

7) A. Sage \& I. Melsa : Estimation Theory with Applications to Communications and Control, McGraw Hill (1971)

8) P. Kaminski, A. Bryson \& F. Schmidt : Discrete Sruare Root Filtering : A Survey of Current Techniques ; IEEE Transactions on Automatic Control, Vol. AC-16, pp. 727 736 (1971)

9) T. Sönderström, L. Ljung \& I. Gustavsson : A Theoretical Analysis of Recursive Identification Methods ; Automatica, Vol. 14, pp. 231 244 (1978)

10) 中溝 : 線形離散システムの同定手法 ; システムと制御, 25 巻, 8 号, pp. 476 480 (1981)

11) I. D. Landau, 富塚: 適応制御システムの理論と実際, オ 一社, p. 58 (1981)

\section{付録 1}

(18) 式の導出

（17）式の右辺を展開すると,

$$
\begin{aligned}
& I-2 \gamma(k+1) Z(k+1) \cdot \boldsymbol{f}(k+1) \boldsymbol{f}^{T}(k+1)+\gamma(k+1)^{2} . \\
& Z(k+1)^{2} \cdot \boldsymbol{f}(k+1) \boldsymbol{f}^{T}(k+1) \boldsymbol{f}(k+1) \boldsymbol{f}^{T}(k+1)
\end{aligned}
$$

を得る. ここで, (16) 式の関係を用いて $\boldsymbol{f}^{T}(k+1) \boldsymbol{f}(k+1)$ を消去して整理すると下式となる.

$$
\begin{aligned}
& I-\left\{2 \gamma(k+1) Z(k+1)-\gamma(k+1)^{2} \cdot Z(k+1)^{2} .\right. \\
& \left.\left(\frac{1}{Z(k+1)}-\lambda_{1}\right)\right\} \cdot \boldsymbol{f}(k+1) \boldsymbol{f}^{T}(k+1) \quad （ \text { 付 }
\end{aligned}
$$

(17) 式より, 本式の \{ $\}$ の部分が $Z(k+1)$ に等しく なるように $\gamma(k+1)$ を定める. すなわち, $\{\quad\}=Z(k+$ 1)として整理すると,

$$
\left(1-\lambda_{1} Z(k+1)\right) \gamma(k+1)^{2}-2 \gamma(k+1)+1=0
$$

となり，本式を解放して $\gamma(k+1)$ を求めると (18) 式と なる。

\section{付録 2}

\section{(23) 式の導出}

(1) パラメータ修正式は基本となる（13）式の第 1 式であ る.

$$
\begin{aligned}
\hat{x}(k+1) & =\hat{x}(k) \\
+ & \boldsymbol{g}(k+1) \cdot\left\{\Delta P_{e}(k+1)-\boldsymbol{a}(k+1) \cdot \hat{x}(k)\right\}
\end{aligned}
$$

（2）ゲインベクトルは，(13）式に（16）式の第 1 式を代 入し， $\lambda_{1} を \sigma_{e}^{2}$ (観測ノイズの分散）と設定すれば, カルマンフィルタに, また, $\delta$ と設定すれば, 指数 荷重型最小自乗法となる. 


$$
g(k+1)=\frac{S(k) \cdot \boldsymbol{f}(k+1)}{\lambda_{1}+\boldsymbol{f}^{T}(k+1) \cdot \boldsymbol{f}(k+1)}
$$

(3) 䛊差共分散行列の平方根行列 $S(k+1)$ については, カルマンフィルタの場合，(19）式に（18）式を代入 して $\lambda_{1}=\sigma_{e}^{2}$ と設定した式となる.

$$
\begin{aligned}
S(k+1)= & S(k)-\frac{Z(k+1)}{1+\sqrt{\lambda_{1} \cdot Z(k+1)}} \\
& \left.\times S(k) \cdot \boldsymbol{f}(k+1) \boldsymbol{f}^{T}(k+1) \quad \text { (付 } 2.2\right)
\end{aligned}
$$

ただし，

$$
Z(k+1)=\frac{1}{\lambda_{1}+\boldsymbol{f}^{T}(k+1) \boldsymbol{f}(k+1)}
$$

一方, 指数荷重型最小自乗法の場合,

$$
\begin{aligned}
S(k+1)= & \frac{1}{\sqrt{\delta}}\left\{S(k)-\frac{Z(k+1)}{1+\sqrt{\delta \cdot Z(k+1)}}\right. \\
& \left.\times S(k) \cdot \boldsymbol{f}(k+1) \boldsymbol{f}^{T}(k+1)\right\} \text { (付 2.4) }
\end{aligned}
$$

ただし，

$$
Z(k+1)=\frac{1}{\delta+\boldsymbol{f}^{T}(k+1) \boldsymbol{f}(k+1)}
$$

である. そこで， $\lambda_{2}, \lambda_{3}$ を用いて，

$$
\begin{aligned}
S(k+1)= & \frac{1}{\sqrt{\lambda_{2}}}\left\{S(k)-\frac{Z(k+1)}{1+\sqrt{\lambda_{2} / \lambda_{3} \cdot Z(k+1)}}\right. \\
& \left.\times S(k) \cdot \boldsymbol{f}(k+1) \boldsymbol{f}^{T}(k+1)\right\} \text { (付 2.6) }
\end{aligned}
$$

ただし，

$$
Z(k+1)=\frac{1}{\lambda_{2} / \lambda_{3}+\boldsymbol{f}^{T}(k+1) \boldsymbol{f}(k+1)} \quad \text { （付 2.7） }
$$

とし， $\lambda$ パラメータを Table. 1 のように設定すれば, (付 2.2), (付 2.3) 式 (カルマンフィル夕) 之（付 2.4), (付 2.5) 式（指数荷重型最小自乗法）を使い分 けることができる．また，入パラメータをすべて 1

とすると, 最小自乗推定となることは明らかである. 